(c) 2018. This manuscript is made available under the CC-BY-NC-ND 4.0 license

\title{
Lung cancer CT screening: psychological responses in the presence and absence of pulmonary nodules
}

\author{
Authors \\ Marcia E Clark - University of Nottingham, Division of Primary Care, Floor 13, Tower Building, \\ University Park, Nottingham, NG7 2RD. \\ Laura E Bedford - University of Nottingham, Division of Primary Care. \\ Ben Young - University of Nottingham, Division of Primary Care. \\ John FR Robertson - University of Nottingham, Division of Medical Sciences and Graduate Medicine. \\ Roshan das Nair - University of Nottingham, Institute of Mental Health. \\ Kavita Vedhara - University of Nottingham, Division of Primary Care. \\ Roberta Littleford - University of Dundee, Tayside Clinical Trials Unit. \\ Francis M Sullivan - University of St Andrews, School of Medicine. \\ Frances S Mair - University of Glasgow, General Practice and Primary Care. \\ Stuart Schembri - University of Dundee, Scottish Centre for Respiratory Research. \\ Petra Rauchhaus - University of Dundee, Tayside Clinical Trials Unit. \\ Denise Kendrick - University of Nottingham, Division of Primary Care - corresponding author.
}

Abstract word count: 275

Manuscript word count - 2828 


\begin{abstract}
Objectives

To determine the psychological response (thoughts, perceptions and affect) to a diagnosis of pulmonary nodules following a novel antibody blood test and computed tomography (CT) scans within a UK population.
\end{abstract}

Materials and methods.

This study was nested within a randomised controlled trial of a blood test (Early CDT ${ }^{\circledR}$-Lung test), followed by a chest $\mathrm{x}$-ray and serial CT-scanning of those with a positive blood test for early detection of lung cancer (ECLS Study). Trial participants with a positive Early CDT ${ }^{\circledR}$-Lung test were invited to participate $(n=338)$ and those agreeing completed questionnaires assessing psychological outcomes at 1, 3 and 6 months following trial recruitment. Responses of individuals with pulmonary nodules on their first CT scan were compared to those without (classified as normal CT) at 3 and 6 months followup using random effects regression models to account for multiple observations per participant, with $\log _{\mathrm{e}}$ transformation of data where modelling assumptions were not met.

Results

There were no statistically significant differences between the nodule and normal CT groups in affect, lung cancer worry, health anxiety, illness perceptions, lung cancer risk perception or intrusive thoughts at 3 or 6 months post-recruitment. The nodule group had statistically significantly fewer avoidance symptoms compared to the normal CT group at 3 months (impact of events scale avoidance (IES-A) difference between means $-1.99,95 \% \mathrm{Cl}-4.18,0.21$ ) than at 6 months (IES-A difference between means $0.88,95 \% \mathrm{Cl}-1.32,3.08 ; \mathrm{p}$-value for change over time $=0.003)$ with similar findings using $\log _{\mathrm{e}}$ transformed data.

Conclusion 
A diagnosis of pulmonary nodules following an Early CDT ${ }^{\oplus}$-Lung test and CT scan did not appear to result in adverse psychological responses compared to those with a normal CT scan.

\section{Keywords}

Pulmonary nodules, lung cancer screening, psychological impact 


\section{Introduction}

Lung cancer is the most common cause of cancer-related deaths worldwide.(1) During 2014 approximately 46,400 individuals in the United Kingdom (UK) were diagnosed with lung cancer.(2) Despite the incidence of lung cancer decreasing(3), mortality rates remain high, with 1-year survival rates ranging from $71 \%$ when diagnosed at stage 1 to $16 \%$ at stage $4 .(4)$

The National Lung Screening Trial (NLST), showed serial computed tomography (CT) scanning was associated with a $20 \%$ reduction in lung cancer mortality.(5) However, screening has potential harms, such as radiation exposure, the detection of non-clinically relevant findings, over-diagnosis and psychosocial harms.(6-11) It is therefore important to ensure acceptability to the population being screened(12), and that overall benefits outweigh the harms.(13)

Assessments of the psychosocial impact of lung cancer screening are limited to studies using CT scanning. The NLST, Pittsburgh Lung Screening Study, and the UK Lung Cancer Screening (UKLS) Trial found increased anxiety in those with true positive screening results compared to those with negative results. The UKLS also found significantly higher cancer worry scale scores 2 weeks after receiving CT scan results in those referred for a repeat CT scan compared to those with negative results. However, absolute differences were small and not thought to be clinically important. (14-17) Additionally, the Dutch-Belgian Randomized Lung Cancer Screening Trial (NELSON trial) and the Pittsburgh Lung Screening Study found increased lung cancer specific distress in those with an indeterminate result, which diminished over time. $(16,18,19)$

As screening with $\mathrm{CT}$ scanning becomes more widespread, more people will be found to have incidental findings, such as pulmonary nodules. Pulmonary nodules are widely defined as round lesions within the lung, less than $3 \mathrm{~cm}$ in diameter and surrounded by normal lung tissue.(20, 21) The NLST reported an incidence of pulmonary nodules of $25.9 \%$ in participants with a pack year history of 
at least 30 years.(5) Several studies used psychological measures to assess the negative impact of a diagnosis of pulmonary nodules(22-25), finding increased emotional distress(22, 23), frustration and fear (25) amongst those with nodules. Additionally, French individuals diagnosed with pulmonary nodules reported lower health-related quality of life (HRQoL) (measured using the SF-36) compared to the French general population.(24)

Our study assesses short and medium-term psychological responses amongst a sample of participants, with or without pulmonary nodule(s) identified on their first CT scan, within the Early Cancer Detection Test-Lung Cancer Scotland Study (ECLS Study).(26) This is a randomised controlled trial assessing the effectiveness of a blood test for lung cancer screening, measuring autoantibodies against seven antigens (Early CDT ${ }^{\circledR}$-Lung test). $(26,27)$ A positive Early CDT ${ }^{\circledR}$-Lung test is associated with a significantly increased risk of malignancy in the presence of pulmonary nodules $4-20 \mathrm{~mm}$ in diameter(28), and the consequent potential for adverse psychological effects. This study is therefore timely in assessing psychological impacts of this test and subsequent CT scanning.

\section{Methods}

This paper presents data on a sub-sample of participants in the ECLS study. Current or ex-smokers aged 50-75 years, with at least 20 pack-years, or fewer pack-years with a first-degree relative with lung cancer from Greater Glasgow and Clyde or Tayside, were randomised 1:1 to an Early CDT ${ }^{\circledR}$-Lung test group or a non-screened control group. All trial participants were asked to complete a baseline questionnaire preceding awareness of group allocation. Those with positive Early CDT ${ }^{\circledR}$-Lung tests were invited for a chest x-ray, followed by a CT scan, and then 6-monthly CT scans for 2 years. Prior to these, they were given information explaining the investigations and the possibility of finding a pulmonary nodule on their CT scan. Individuals were informed of their CT scan result in writing. 
Participants who had previously consented to be contacted and those with a positive Early CDT ${ }^{\oplus}$-Lung test were invited to participate in this nested psychological outcomes study. Those agreeing completed additional questionnaires at $1,3,6,12,18$ and 24 months collecting data on psychological and behavioural outcomes. Participants were sent a $£ 5$ gift voucher for each questionnaire completed. Postal and telephone reminders were used for non-responders. No further questionnaires were sent to participants who were non-responsive to two consecutive questionnaires. On completing the 1-month questionnaire, all participants would have been aware that their Early $\mathrm{CDT}^{\oplus}$-Lung test was positive, but $58 \%$ of participants had not yet had their CT scan, $18 \%$ had been scanned within the last 7 days, $37 \%$ within the last 14 days and $8 \%$ more than 14 days previously. Consequently, at 1-month follow-up most participants will not have known their CT scan results. The analyses presented in this paper are therefore confined to the psychological outcomes of Early $\mathrm{CDT}^{\circledR}$-positive group participants who completed baseline and at least one follow-up questionnaire at 3 or 6 months. Participants were categorised into the nodule group if pulmonary nodule(s) $\leq 8 \mathrm{~mm}$ in diameter were present on their first CT scan and into the normal CT group if they were absent (normal CT group participants may have had previously known stable pathology). Study ineligibility criteria can be found in Figure 1.

\section{Data collection}

Baseline information was collected at trial recruitment, between December 2013 and April 2015 and included age, gender, smoking history, ethnic group, marital status, postcode, age at leaving full time education, employment status, family history of lung cancer (first-degree relative) and antidepressant medication use.

Psychological measures included the positive and negative affect schedule (PANAS)(29), lung cancer worry scale (LCWS)(30), health anxiety subscale (HAS) of the health orientation scale(31), the impact of events scale (IES)(32), the revised illness perception questionnaire-adapted for lung cancer 
$(I P Q-R)(33)$, and lung cancer risk perception. The time points at which these were collected, descriptions and internal consistency of measures are shown in Supplementary Table 1.

\section{Analysis}

Data analysis was undertaken using Stata Statistical Software version 13.1.(34) Baseline characteristics of those in the normal CT and nodule groups were described using frequencies and percentages for categorical data and medians and interquartile ranges (IQR) for non-normally distributed continuous data. For ease of interpretation, means and standard deviations are also presented. Groups were compared using chi-squared tests and Mann-Whitney $\mathrm{U}$ tests for categorical and continuous variables respectively. Fisher's exact test was used for ethnicity due to small values.

Multilevel (random effects) regression models were used to compare psychological measures between the normal CT and nodule groups over time and to take account of multiple observations per participant. Linear models were used for continuous variables and logistic models for categorical variables. Models were adjusted for study centre, age group (50-54, 55-59, 60-64, 65-69, 70-74, 75-79 years), sex, smoking status, time ( 3 and 6 months) and where measured, baseline value of the outcome variable. Analyses were repeated additionally adjusting for baseline antidepressant use and family history of lung cancer.

Linearity of continuous covariates was checked by adding higher order terms to models. Differences in outcomes over time between the normal and CT and nodule groups were assessed by adding a group by time interaction and using likelihood ratio tests with $p<0.01$ taken as significant. Between-group differences at each time point were estimated from these models. Model assumptions were checked by plotting residual values and by excluding observations with large residual values (<$3,>3$ ). Where residuals were not normally distributed or variance was not constant, continuous outcome measures were $\log _{\mathrm{e}}$ transformed (adding 1 to the IES-I and IES-A scores before 
transformation as some participants scored zero) and model assumptions were re-checked. Where $\log _{\mathrm{e}}$ transformed models met assumptions better, we present findings on the original scale and the $\log _{\mathrm{e}}$ transformed scale for ease of interpretation. We were unable to find a single standardised method for handling missing data for the psychological measures. Single missing values were therefore replaced with the mean or subscale score for the participant for PANAS, HAS, LCWS Impact Score and IES. When more than one value was missing the scale score was considered to be missing.

\section{Results}

Three hundred and thirty eight Early CDT ${ }^{\circledR}$-Lung test-positive ECLS trial participants took part in the psychological outcomes study, 269 (174 in the normal CT group and 95 in the nodule group) of whom were eligible to be included in the analyses presented in this paper (Figure 1). Response rates to follow-up questionnaires were high. The analysis included $95 \%$ at 3 months and $94 \%$ at 6 months. All participants were aware of their CT scan result on completing the 3-month questionnaire.

\section{Baseline demographic and psychological measures}

Table 1 shows baseline demographic characteristics by nodule status. There were no statistically significant differences between the nodule and normal CT groups. Psychological measures at baseline are shown in Table 2. The only statistically significant difference was that nodule group participants had significantly higher $(\mathrm{P}=0.04)$ positive affect PANAS scores than normal $\mathrm{CT}$ group participants (median (IQR) $37.4(27,41.6)$ vs. $32(26.7,39))$.

\section{Psychological measures at 3 and 6 months follow-up}

Psychological measure scores at 3 and 6 months are shown in Table 3 and Table 4 shows adjusted differences between means and odds ratios comparing the nodule to the normal CT group at 3 and 6 months. The nodule group had statistically significantly fewer avoidance symptoms compared to the normal CT group at 3 months (difference between means in impact of events scale avoidance (IES-A) 
score $-1.99,95 \% \mathrm{Cl}-4.18,0.21$ ) than at 6 months (difference between means in IES-A score $0.88,95 \% \mathrm{Cl}$ $-1.32,3.08$; P-value for change over time=0.003). However, the differences in means between the nodule and normal CT groups were small at both time points. Table 5 shows differences between the means of $\log _{\mathrm{e}}$ transformed data for outcomes where model assumptions were better met using transformed data. Findings were similar to those using data on the original scale with lower IES-A scores in the nodule than the normal CT group at 3 months (difference in $\log _{\mathrm{e}}$ transformed means $-0.34(-0.65,-0.04)$ than at 6 months (difference in $\log _{\mathrm{e}}$ transformed means $\left.-0.06(-0.36,0.24)\right)$ but the change over time did not reach statistical significance $(P=0.04)$. No other statistically significant differences between means or odds ratios were seen over time. Adjusting the models for whether participants took antidepressant medication at baseline or had a family history of lung cancer had little impact on the findings. Models were robust to exclusion of observations with large residual values.

\section{Discussion}

Summary

This study demonstrates that a diagnosis of pulmonary nodules on a CT scan following an Early CDT ${ }_{-}$ Lung positive result for lung cancer screening does not result in an adverse psychological response in relation to affect, health anxiety, thought intrusion and illness perception compared to those who had a normal CT scan in both the short and medium-term. Although those in the nodule group had statistically significantly fewer avoidance behaviours than those in the normal CT group at 3 months than at 6 months, the differences between the mean scores in the nodule and normal CT groups were small at both time points.

\section{Strengths and limitations}

To our knowledge, this is the first study examining the psychological impact of receiving a pulmonary nodule diagnosis following a novel antibody test and chest CT scan within a UK population. Strengths 
of our study include use of a range of psychological outcome measures, which included positive as well as negative psychological responses, measures were repeated at multiple time points, a very high follow-up rate and analyses were adjusted for baseline measures where possible. However, it is possible that there may be small but potentially clinically important differences, which we did not have sufficient power to detect. Although a lower p-value (0.01) was used for significance testing of changes in scores between groups over time, multiple significance testing may have resulted in significant findings for the IES avoidance score. However, even if our IES Avoidance score findings are not due to type 1 error, differences in mean scores between the nodule and normal CT group were small and unlikely to be clinically meaningful.(18) As we did not know whether participants had received their CT scan result at the time of completing the 1-month questionnaire, this study does not evaluate the immediate response to receiving a pulmonary nodule diagnosis.

\section{Comparison with existing literature}

Previous studies examining the psychological impact of a pulmonary nodule diagnosis have found contrasting results. $(18,19,24,35,36)$ Two studies in America found that individuals diagnosed with pulmonary nodules reported emotional distress (measured using the IES) shortly after diagnosis (time not specified)(35) and up to 2 or more years after diagnosis $(19,36)$.These findings differ from our study and those of the NELSON trial, with the latter showing an early (2 months after diagnosis)(18) and temporary clinically important increase in IES scores in individuals with nodules.(19) Additionally, the NELSON trial did not find that health-related quality of life (HRQoL) was affected by a pulmonary nodule diagnosis (19), which contrasts with a study in France.(24) This found a significantly lower HRQoL at 6-months post-diagnosis in those with pulmonary nodules compared to the French general population.(24) There are multiple factors that could explain the differences seen between these studies and ours. These include differences in screening procedures (our study used the Early CDT ${ }^{\circledR}$ Lung test to identify those for CT scanning whereas other studies used CT screening alone or included participants found to have pulmonary nodules during routine clinical care), study populations, timing 
of questionnaire administration, definitions of pulmonary nodules, mode of nodule detection (screened versus incidentally detected), whether the study compared to a control group and whether adjustments were made for baseline measures. Additionally, our study participants received information explaining pulmonary nodules prior to their radiological investigations and enclosed with their CT scan results.

It is not possible to directly equate the findings of this study with those of the UKLS, which did not compare individuals with pulmonary nodules to those with a normal CT.(15, 17) Participants with pulmonary nodules will have been included in the UKLS "repeat scan required group" for the 2-week outcomes analysis and in the "false positive" group for the up to 2-years outcome analysis. A statistically significant, but not clinically important, increase in lung cancer worry was found at 2 weeks in those needing repeat scans compared to those with a negative CT scan result. No other statistically significant or clinically important differences were found in lung cancer worry, anxiety or depression at 2 weeks or up to 2 years, which is consistent with our findings.

There are several potential explanations for our finding that participants in the nodule group had a more positive psychological response (lower avoidance scores) than the normal CT group. It is possible that receiving a positive Early $\mathrm{CDT}^{\oplus}$-Lung test psychologically prepared participants to receive an abnormal CT scan result, leading to a more positive psychological response than in studies where the CT scan is the first abnormal result a participant receives. Furthermore, receiving a diagnosis of pulmonary nodules after a positive Early $\mathrm{CDT}^{\circledR}{ }^{\circledR}$ Lung test may have provided participants with reassurance, as this may be perceived as an "explanation" for the positive Early CDT ${ }^{\circledR}$-Lung test, whilst those with a normal CT scan may have interpreted this as contradictory to the blood test finding, and experienced a lack of reassurance. It is also possible that participants with a positive Early CDT ${ }^{\circledR}$-Lung test were preparing themselves psychologically to receive a CT result suspicious for lung cancer, and a diagnosis of pulmonary nodules may have been perceived as a much more favourable outcome, with 
a more positive psychological response. The manner in which the CT results were communicated may also have been important in determining the psychological response. Those with pulmonary nodules were sent their results by letter. This said the scan was satisfactory but had shown small nodules within one of the lungs which were less than $8 \mathrm{~mm}$ in size and were most likely to be of little health concern. The letter also offered the option to discuss their scan results face-to-face with a doctor from the study team. In addition, participants were advised that the nodules would be monitored with further CT scans and any changes in nodules would result in a face-to-face discussion with a doctor. There was a also a small but statistically significant difference in positive affect scores at baseline, with the nodule group having a higher score than those with a normal CT. Higher positive affect scores have been associated with a lower incidence of psychological illness,(37) so this may also potentially explain our finding of lower avoidance scores in those with nodules than in those with a normal CT at 3 months.

\section{Implications for research and practice}

Our findings provide some reassurance to clinicians concerned about the potential harms of lung cancer screening using a novel blood antibody test followed by serial CT scanning, should it be more widely implemented. There is likely to be little impact on health services in terms of emotionally distressed patients seeking help after pulmonary nodules being found on screening CT scans. Further work is required to explore the short-term impact (i.e. within a month) of a diagnosis of pulmonary nodules in the context of a screening programme and patients' understanding of the results of both blood tests and CT scans, and the impact of their understanding on psychological responses.

\section{Trial Registration}

ClinicalTrials.gov: NCT01925625.

\section{Funding}


This study was carried out as part of a National Institute for Health Research (NIHR) School for Primary Care Research (SPCR) funded academic clinical fellowship. The views expressed are those of the author(s) and not necessarily those of the NIHR, the NHS or the Department of Health. The ECLS study was funded by the Scottish Executive and Oncimmune Ltd. The follow-up data collection was funded by University of Nottingham PhD studentships and by Oncimmune Ltd.

\section{Ethical approval}

Ethical approval was given by the East of Scotland Research Ethics Service as an amendment to the main ECLS study: REC reference 13/ES/0024, amendment number AM16.

\section{Competing Interests}

The University of Dundee received funding from the Scottish Executive, the University of Glasgow received funding from the Scottish Executive and Oncimmune Ltd and the University of Nottingham received funding from Oncimmune Ltd to conduct this research. Marcia Clark was funded by an NIHR School for Primary Care Research Academic Clinical Fellowship and Laura Bedford and Ben Young were funded by University of Nottingham PhD studentships.

John Robertson reports grants from AstraZeneca, personal fees from AstraZeneca, other from AstraZeneca, grants from Novartis, personal fees from Bayer, personal fees and other from Carrick Therapeutics, outside the submitted work. In addition, Professor Robertson has a patent (multiple patents) licensed to Oncimmune, and a patent (multiple patents) issued and shares and share options in Oncimmune but have not had any company involvement for over 4 years.

The funding sources had no role in the design of this study, its execution, analyses, interpretation of the data, or decision to submit results. 


\section{Acknowledgements}

We thank the ECLS trial staff for recruiting participants and collecting baseline data from the trial participants. We gratefully acknowledge the contribution to this study and publication made by the Tayside Clinical Trials Unit (TCTU).

\section{References}

1. Ferlay J, Soerjomataram I, Dikshit R, Eser S, Mathers C, Rebelo M, et al. Cancer incidence and mortality worldwide: Sources, methods and major patterns in GLOBOCAN 2012. International Journal of Cancer. 2015;136(5):E359-E86.

2. Cancer Research UK. [July 2016]; Available from: http://www.cancerresearchuk.org/healthprofessional/cancer-statistics/statistics-by-cancer-type/lung-cancer\#heading-Zero.

3. National Cancer Intelligence Network. Recent trends in lung cancer incidence, mortality and survival. Available from:http://www.ncin.org.uk/publications/. Accessed 18/5/18.

4. Walters S, Maringe C, Coleman MP, Peake MD, Butler J, Young N, et al. Lung cancer survival and stage at diagnosis in Australia, Canada, Denmark, Norway, Sweden and the UK: a populationbased study, 2004-2007. Thorax. 2013;68(6):551-64.

5. The National Lung Screening Trial Research Team. Reduced Lung-Cancer Mortality with LowDose Computed Tomographic Screening. New England Journal of Medicine. 2011;365(5):395-409.

6. Bach PB, Mirkin JN, Oliver TK, et al. Benefits and harms of CT screening for lung cancer: A systematic review. JAMA. 2012;307(22):2418-29.

7. Gill RR, Jaklitsch MT, Jacobson FL. Controversies in Lung Cancer Screening. Journal of the American College of Radiology : JACR. 2016;13(2 Suppl):R2-7. Epub 2016/02/06.

8. Harris RP, Sheridan SL, Lewis CL, Barclay C, Vu MB, Kistler CE, et al. The harms of screening: a proposed taxonomy and application to lung cancer screening. JAMA internal medicine. 2014;174(2):281-5. Epub 2013/12/11.

9. Jha S. Thinking Beyond the Treatment Effect in Screening for Lung Cancer. Academic radiology. 2015;22(8):983-4.

10. Nanavaty $P$, Alvarez MS, Alberts WM. Lung cancer screening: advantages, controversies, and applications. Cancer control : journal of the Moffitt Cancer Center. 2014;21(1):9-14. Epub 2013/12/21. 11. Pinsky PF. Assessing the benefits and harms of low-dose computed tomography screening for lung cancer. Lung cancer management. 2014;3(6):491-8. Epub 2014/01/01.

12. Wilson JMG, Jungner G. Principles and practice of screening for disease. World Health Organisation, Geneva. 1968.

13. Nielsen C, Lang RS. Principles of screening. Medical Clinics of North America. 1999;83(6):1323-

37.

14. Gareen IF, Duan F, Greco EM, Snyder BS, Boiselle PM, Park ER, et al. Impact of lung cancer screening results on participant health-related quality of life and state anxiety in the National Lung Screening Trial. Cancer. 2014;120(21):3401-9. Epub 2014/07/30.

15. Field JK, Duffy SW, Baldwin DR, Brain KE, Devaraj A, Eisen T, et al. The UK Lung Cancer Screening Trial: a pilot randomised controlled trial of low-dose computed tomography screening for the early detection of lung cancer. Health technology assessment (Winchester, England). 2016;20(40):1-146. Epub 2016/05/26.

16. Byrne MM, Weissfeld J, Roberts MS. Anxiety, fear of cancer, and perceived risk of cancer following lung cancer screening. Medical decision making : an international journal of the Society for Medical Decision Making. 2008;28(6):917-25. Epub 2008/08/30. 
17. Brain K, Lifford KJ, Carter B, Burke O, McRonald F, Devaraj A, et al. Long-term psychosocial outcomes of low-dose CT screening: results of the UK Lung Cancer Screening randomised controlled trial. Thorax. 2016;71(11):996-1005. Epub 2016/07/30.

18. van den Bergh KA, Essink-Bot ML, Borsboom GJ, Th Scholten E, Prokop M, de Koning HJ, et al. Short-term health-related quality of life consequences in a lung cancer CT screening trial (NELSON). British journal of cancer. 2010;102(1):27-34. Epub 2009/11/26.

19. van den Bergh KA, Essink-Bot ML, Borsboom GJ, Scholten ET, van Klaveren RJ, de Koning HJ. Long-term effects of lung cancer computed tomography screening on health-related quality of life: the NELSON trial. The European respiratory journal. 2011;38(1):154-61. Epub 2010/12/15.

20. Callister MEJ, Baldwin DR, Akram AR, Barnard S, Cane P, Draffan J, et al. British Thoracic Society guidelines for the investigation and management of pulmonary nodules: accredited by NICE. Thorax. 2015;70(Suppl 2):ii1-ii54.

21. Folch EE, Mazzone PJ. Assessment of solitary pulmonary nodule BMJ Best Practice. 2015.

22. Slatore CG, Press N, Au DH, Curtis JR, Wiener RS, Ganzini L. What the Heck is a "Nodule"? A Qualitative Study of Veterans with Pulmonary Nodules. Annals of the American Thoracic Society. 2013;10(4):330-5.

23. Sullivan DR, Golden SE, Ganzini L, Hansen L, Slatore CG. 'I still don't know diddly': a longitudinal qualitative study of patients' knowledge and distress while undergoing evaluation of incidental pulmonary nodules. NPJ primary care respiratory medicine. 2015;25:15028. Epub 2015/06/02.

24. Lemonnier I, Baumann C, Jolly D, Arveux P, Woronoff-Lemsi MC, Velten M, et al. Solitary pulmonary nodules: consequences for patient quality of life. Quality of life research : an international journal of quality of life aspects of treatment, care and rehabilitation. 2011;20(1):101-9. Epub 2010/08/10.

25. Wiener RS, Gould MK, Woloshin S, Schwartz LM, Clark JA. "The thing is not knowing": Patients' perspectives on surveillance of an indeterminate pulmonary nodule. Health expectations : an international journal of public participation in health care and health policy. 2015;18(3):355-65.

26. Sullivan FM, Farmer E, Mair FS, Treweek S, Kendrick D, Jackson C, et al. Detection in blood of autoantibodies to tumour antigens as a case-finding method in lung cancer using the EarlyCDT ${ }^{\circledR}$-Lung Test (ECLS): study protocol for a randomized controlled trial. BMC cancer. 2017;17(1):187.

27. Chapman CJ, Healey GF, Murray A, Boyle P, Robertson C, Peek LJ, et al. EarlyCDT ${ }^{\circledR}$-Lung test: improved clinical utility through additional autoantibody assays. Tumour Biology. 2012;33(5):1319-26. 28. Massion PP, Healey GF, Peek LJ, Fredericks L, Sewell HF, Murray A, et al. Autoantibody Signature Enhances the Positive Predictive Power of Computed Tomography and Nodule-Based Risk Models for Detection of Lung Cancer. Journal of thoracic oncology : official publication of the International Association for the Study of Lung Cancer. 2016. Epub 2016/09/13.

29. Watson D, Clark LA, Tellegen A. Development and validation of brief measures of positive and negative affect: The PANAS scales. Journal of Personality and Social Psychology. 1988;54(6):1063-70.

30. Lerman C, Trock B, Rimer BK, Jepson C, Brody D, Boyce A. Psychological side effects of breast cancer screening. Health Psychology. 1991;10(4):259-67.

31. Snell WE, Johnson G, Lloyd PJ, Hoover MW. The Health Orientation Scale: A measure of psychological tendencies associated with health. European Journal of Personality. 1991;5(2):169-83.

32. Horowitz M, Wilner N, Alvarez W. Impact of Event Scale: a measure of subjective stress. Psychosomatic medicine. 1979;41(3):209-18. Epub 1979/05/01.

33. Moss-Morris R, Weinman J, Petrie K, Horne R, Cameron L, Buick D. The Revised Illness Perception Questionnaire (IPQ-R). Psychology \& Health. 2002;17(1):1-16.

34. StataCorp. Stata Statistical Software. Texas.

35. Slatore CG, Golden SE, Ganzini L, Wiener RS, Au DH. Distress and Patient-Centered Communication among Veterans with Incidental (Not Screen-Detected) Pulmonary Nodules. A Cohort Study. Annals of the American Thoracic Society. 2015;12(2):184-92.

36. Freiman MR, Clark JA, Slatore CG, Gould MK, Woloshin S, Schwartz LM, et al. Patients' Knowledge, Beliefs, and Distress Associated with Detection and Evaluation of Incidental Pulmonary 
Nodules for Cancer: Results from a Multicenter Survey. Journal of thoracic oncology : official publication of the International Association for the Study of Lung Cancer. 2016;11(5):700-8. Epub 2016/03/11.

37. Crawford JR, Henry JD. The positive and negative affect schedule (PANAS): construct validity, measurement properties and normative data in a large non-clinical sample. The British journal of clinical psychology / the British Psychological Society. 2004;43(Pt 3):245-65. Epub 2004/08/31.

Figure 1. Number of ECLS participants eligible for inclusion within the study at each questionnaire time-point.

Table 1. Psychological measures included in the questionnaires, with a brief description of each measure.

Table 2. Demographic characteristics at baseline amongst participants in the nodule group and those in the normal CT group (\% indicates column percentage unless otherwise stated).

Table 3. Psychological measures at baseline amongst participants in the nodule group and those in the normal CT group (\% indicates column percentage unless otherwise stated).

Table 4. Psychological measures at 1,3 and 6 months amongst participants in the nodule group and those in the normal CT group (\% indicates column percentage unless otherwise stated).

Table 5. Difference between means and odds ratios for psychological measures at 1, 3 and 6 months comparing participants in the nodule group to those in the normal CT group. 
Figure 1. Number of ECLS participants eligible for inclusion within the study at each questionnaire time-point.

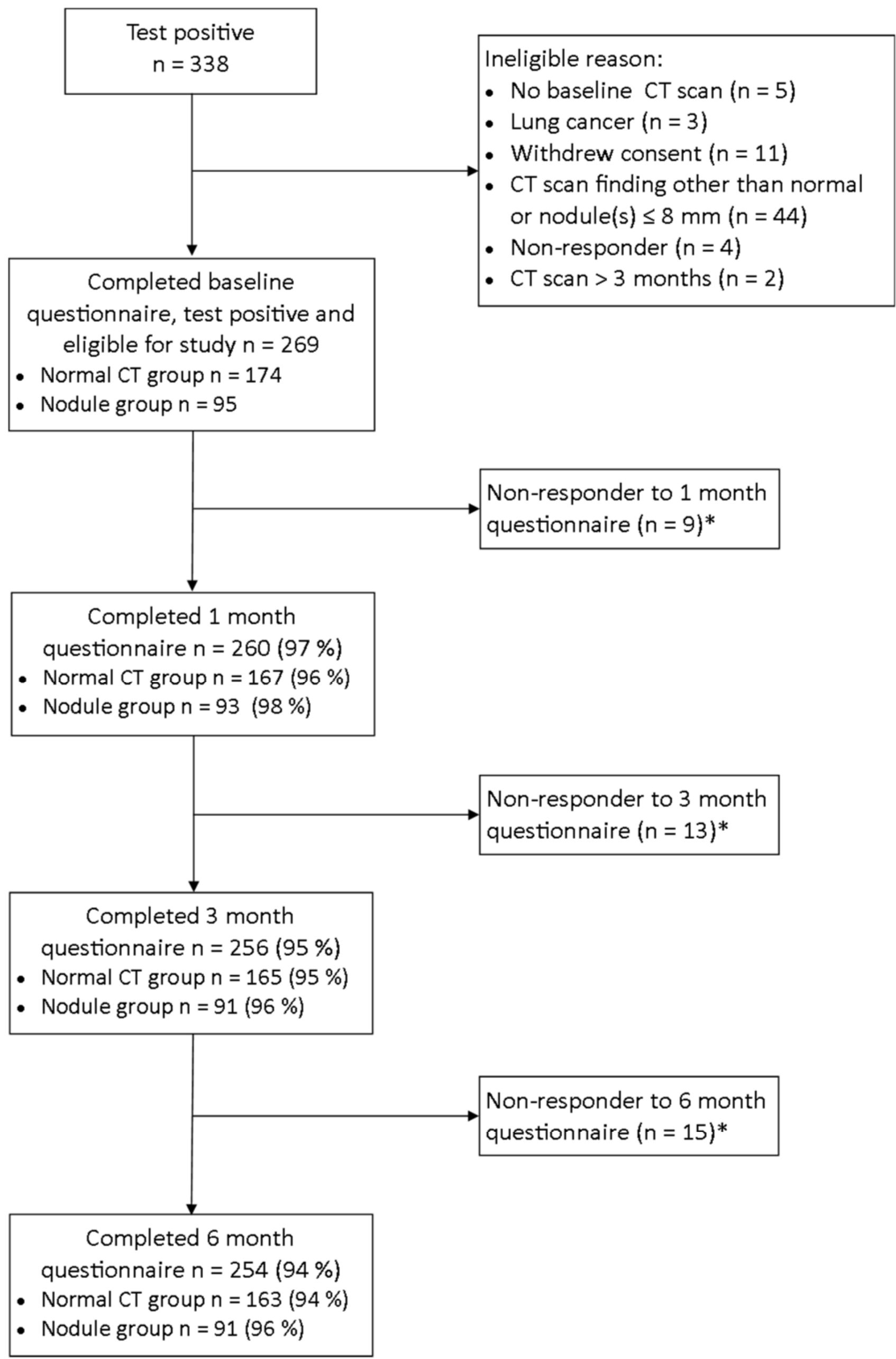


Table 1. Demographic characteristics at baseline amongst participants in the nodule group and those in the normal CT group (\% indicates column percentage unless otherwise stated).

\begin{tabular}{|c|c|c|c|}
\hline Variable & $\begin{array}{c}\text { Nodule } \\
\mathrm{n}=95(\%)\end{array}$ & $\begin{array}{l}\text { Normal CT } \\
n=174(\%)\end{array}$ & Statistical Test \\
\hline $\begin{array}{l}\text { Study Centre } \\
\text { Glasgow } \\
\text { Tayside }\end{array}$ & $\begin{array}{l}72(75.8) \\
23(24.2)\end{array}$ & $\begin{array}{c}123(70.7) \\
51(29.3)\end{array}$ & $\chi^{2}(1)=0.80, p=0.37$ \\
\hline $\begin{array}{l}\left.\text { Age (years - median }\left(I Q R^{*}\right)\right) \\
50-54 \text { years } \\
55-59 \text { years } \\
60-64 \text { years } \\
65-69 \text { years } \\
70-74 \text { years } \\
75-79 \text { years }\end{array}$ & $\begin{array}{c}61(56,67) \\
17(17.9) \\
22(23.2) \\
21(22.1) \\
23(24.2) \\
12(12.6) \\
0(0)\end{array}$ & $\begin{array}{c}60(55,66) \\
37(21.3) \\
48(27.6) \\
31(17.8) \\
40(23.0) \\
15(8.6) \\
3(1.7)\end{array}$ & $\begin{array}{c}z=-1.30, p=0.19 \\
\chi^{2}(5)=4.06, p=0.54\end{array}$ \\
\hline $\begin{array}{l}\text { Gender } \\
\text { Male } \\
\text { Female }\end{array}$ & $\begin{array}{l}39(41.1) \\
56(58.9)\end{array}$ & $\begin{array}{l}80(46.0) \\
94(54.0)\end{array}$ & $\chi^{2}(1)=0.60, p=0.44$ \\
\hline $\begin{array}{l}\text { Smoking Status } \\
\text { Current smoker } \\
\text { Ex-smoker }\end{array}$ & $\begin{array}{l}50(52.6) \\
45(47.4)\end{array}$ & $\begin{array}{l}88(50.6) \\
86(49.4)\end{array}$ & $\chi^{2}(1)=0.10, p=0.75$ \\
\hline Smoking Pack-year (median (IQR)) & $35(26,48)$ & $32.5(25,49)$ & $z=-0.83, p=0.41$ \\
\hline $\begin{array}{l}\text { Ethnic Origin } \\
\text { White British } \\
\text { Other }\end{array}$ & $\begin{array}{c}{[0]} \\
93(97.9) \\
2(2.1)\end{array}$ & $\begin{array}{c}{[4]} \\
165(97.1) \\
5(2.9)\end{array}$ & Fisher's exact $p=1.00$ \\
\hline $\begin{array}{l}\text { Marital Status } \\
\text { Single } \\
\text { In a relationship/married/civil partnership } \\
\text { Widowed } \\
\text { Separated/divorced }\end{array}$ & $\begin{array}{c}{[0]} \\
5(5.3) \\
67(70.5) \\
10(10.5) \\
13(13.7)\end{array}$ & $\begin{array}{c}{[5]} \\
15(8.9) \\
103(61.0) \\
17(10.0) \\
34(20.1)\end{array}$ & $\chi^{2}(3)=3.34, p=0.34$ \\
\hline $\begin{array}{l}\text { Scottish Index of Multiple Deprivation } \\
\text { (Rank) } \\
1-1395 \text { (most deprived) } \\
1396-2790 \\
2791-4186 \\
4187-5581 \\
5582-6976 \text { (least deprived) }\end{array}$ & $\begin{aligned} & 35(36.8) \\
& 27(28.4) \\
& 14(14.7) \\
& 8(8.4) \\
& 11(11.6)\end{aligned}$ & $\begin{array}{l}68(39.1) \\
42(24.1) \\
27(15.5) \\
23(13.2) \\
14(8.1)\end{array}$ & $\chi^{2}(4)=2.60, p=0.63$ \\
\hline $\begin{array}{l}\text { Prescribed medication for low mood } \\
\text { Yes } \\
\text { No }\end{array}$ & $\begin{array}{c}{[1]} \\
11(11.7) \\
83(88.3)\end{array}$ & $\begin{array}{c}{[4]} \\
30(17.7) \\
140(82.4)\end{array}$ & $\chi^{2}(1)=1.63, p=0.20$ \\
\hline $\begin{array}{l}\text { Age at leaving full-time education (years - } \\
\text { median (IQR)) }\end{array}$ & $\begin{array}{c}{[2]} \\
16(15,16)\end{array}$ & $\begin{array}{c}{[7]} \\
16(15,16)\end{array}$ & $z=0.29, p=0.77$ \\
\hline $\begin{array}{l}\text { Work Status } \\
\text { Employed } \\
\text { Unemployed } \\
\text { Retired/other }\end{array}$ & $\begin{array}{c}{[0]} \\
40(42.1) \\
16(16.8) \\
39(41.1)\end{array}$ & $\begin{array}{c}5] \\
75(44.4) \\
33(19.5) \\
61(36.1)\end{array}$ & $\chi^{2}(2)=0.70, p=0.70$ \\
\hline $\begin{array}{l}\text { First degree relative with lung cancer } \\
\text { No } \\
\text { Yes }\end{array}$ & $\begin{array}{l}70(73.7) \\
25(26.3)\end{array}$ & $\begin{array}{c}115(66.1) \\
59(33.9)\end{array}$ & $\chi^{2}(1)=1.65, p=0.20$ \\
\hline
\end{tabular}

[missing values] *Interquartile range 
Table 2. Psychological measures at baseline amongst participants in the nodule group and those in the normal CT group (\% indicates column percentage unless otherwise stated).

\begin{tabular}{|c|c|c|c|}
\hline Psychological Measure & $\begin{array}{c}\text { Nodule } \\
\mathrm{n}=95(\%)\end{array}$ & $\begin{array}{l}\text { Normal CT } \\
n=174(\%)\end{array}$ & $\begin{array}{c}\text { Statistical } \\
\text { Test }\end{array}$ \\
\hline $\begin{array}{l}\text { Positive and Negative Affect Schedule (PANAS) } \\
\text { Positive affect score (median (IQR*)) } \\
\text { (mean (SD**)) } \\
\text { Negative affect score (median (IQR)) } \\
\text { (mean (SD)) }\end{array}$ & $\begin{array}{c}3] \\
37.4(27,41.6) \\
34.5(9.2) \\
13(11,18) \\
15.6(6.4)\end{array}$ & $\begin{array}{c}{[5]} \\
32(26.7,39) \\
32.4(8.8) \\
13(11,18) \\
15.7(6.5)\end{array}$ & $\begin{array}{l}z=-2.02 \\
p=0.04 \\
z=-0.06 \\
p=0.96\end{array}$ \\
\hline $\begin{array}{l}\text { Lung Cancer Worry Scale } \\
\text { How worried are you about getting lung cancer someday? } \\
\text { Not worried } \\
\text { Worried } \\
\text { What is your current anxiety level about the results of } \\
\text { future tests/treatments? } \\
\text { Not anxious } \\
\text { Anxious } \\
\text { Impact of worry } \\
\text { Median (IQR) } \\
\text { (mean (SD)) }\end{array}$ & $\begin{array}{c}{[2]} \\
46(49.5) \\
47(50.5) \\
\\
{[2]} \\
87(93.6) \\
6(6.4) \\
{[2]} \\
2(2,3) \\
2.9(1.3) \\
\end{array}$ & $\begin{array}{c}{[2]} \\
66(38.4) \\
106(61.6) \\
{[2]} \\
153(89.0) \\
19(11.0) \\
{[2]} \\
3(2,3) \\
3.0(1.4) \\
\end{array}$ & $\begin{array}{l}\chi^{2}(1)=1.49 \\
p=0.22 \\
z=1.44 \\
p=0.15\end{array}$ \\
\hline $\begin{array}{l}\text { Illness Perception Questionnaire (IPQ-R) } \\
\text { What I do can affect my risk of getting lung cancer } \\
\text { Agree } \\
\text { Disagree } \\
\text { When I think about my risk of getting lung cancer I get } \\
\text { upset } \\
\text { Agree } \\
\text { Disagree } \\
\text { I do not know how likely it is that I might get lung cancer } \\
\text { Agree } \\
\text { Disagree } \\
\text { Finding lung cancer early can improve my chances of } \\
\text { survival } \\
\text { Agree } \\
\text { Disagree } \\
\text { Lung cancer would have a big impact on my life } \\
\text { Agree } \\
\text { Disagree } \\
\text { Lung cancer lasts for a long time } \\
\text { Agree } \\
\text { Disagree } \\
\text { A blood screening test can accurately detect lung cancer } \\
\text { Agree } \\
\text { Disagree }\end{array}$ & $\begin{array}{c}{[1]} \\
85(90.4) \\
9(9.6) \\
{[1]} \\
43(45.7) \\
51(54.3) \\
{[2]} \\
60(64.5) \\
33(35.5) \\
{[2]} \\
88(94.6) \\
5(5.4) \\
{[2]} \\
89(95.7) \\
4(4.3) \\
{[2]} \\
60(64.5) \\
33(35.5) \\
{[1]} \\
60(63.8) \\
34(36.2)\end{array}$ & $\begin{array}{c}{[4]} \\
153(90.0) \\
17(10.0) \\
{[4]} \\
78(45.9) \\
92(54.1) \\
{[6]} \\
116(66.7) \\
56(33.3) \\
{[2]} \\
165(95.9) \\
7(4.1) \\
{[3]} \\
167(97.7) \\
4(2.3) \\
{[2]} \\
106(61.6) \\
66(38.4) \\
{[3]} \\
106(62.0) \\
65(38.0)\end{array}$ & $\begin{array}{c}\chi^{2}(1)=0.01 \\
p=0.91 \\
\chi^{2}(1)=0.001 \\
p=0.98 \\
\chi^{2}(1)=0.12 \\
p=0.73 \\
\chi^{2}(1)=0.24 \\
p=0.63 \\
\chi^{2}(1)=0.79 \\
p=0.37 \\
\chi^{2}(1)=0.22 \\
p=0.64 \\
\chi^{2}(1)=0.09 \\
p=0.77\end{array}$ \\
\hline $\begin{array}{l}\text { Lung Cancer Risk Perception } \\
\text { What are the chances that you will develop lung cancer } \\
\text { over the next } 5 \text { years? } \\
\leq 0.4 \% \text { (low risk)/Don't know } \\
\geq 1 \% \text { (high risk) } \\
\text { Compared to other people of your age and sex, how likely } \\
\text { are you to develop lung cancer over the next } 5 \text { years? } \\
\text { Less likely/Don't know } \\
\text { More likely }\end{array}$ & $\begin{array}{c}{[0]} \\
85(89.5) \\
10(10.5) \\
{[0]} \\
50(52.6) \\
45(47.4)\end{array}$ & $\begin{array}{c}{[2]} \\
153(89.0) \\
19(11.0) \\
{[2]} \\
82(47.7) \\
90(52.3)\end{array}$ & $\begin{array}{c}\chi^{2}(1)=0.60 \\
p=0.44\end{array}$ \\
\hline
\end{tabular}

[Missing values] *Interquartile range **Standard deviation 
Table 3. Psychological measures at 3 and 6 months amongst participants in the nodule group and those in the normal CT group (\% indicates column percentage unless otherwise stated).

\begin{tabular}{|c|c|c|c|c|}
\hline \multirow[t]{2}{*}{ Psychological Measure } & \multicolumn{2}{|c|}{3 months } & \multicolumn{2}{|c|}{6 months } \\
\hline & $\begin{array}{c}\text { Nodule } \\
n=91(\%)\end{array}$ & $\begin{array}{l}\text { Normal CT } \\
n=165(\%)\end{array}$ & $\begin{array}{c}\text { Nodule } \\
n=91(\%)\end{array}$ & $\begin{array}{l}\text { Normal CT } \\
n=163(\%)\end{array}$ \\
\hline $\begin{array}{l}\text { Positive and Negative Affect Schedule (PANAS) } \\
\text { Positive affect score } \\
\text { Median (IQR*) } \\
\text { (mean (SD**)) } \\
\text { Negative affect score } \\
\text { Median (IQR) } \\
\text { (mean (SD)) }\end{array}$ & $\begin{array}{c}{[1]} \\
32.5(25-40) \\
32.1(10.0) \\
{[1]} \\
14(11,22) \\
16.7(7.6)\end{array}$ & $\begin{array}{c}{[3]} \\
30(24-35) \\
29.3(8.5) \\
{[3]} \\
13(11,20) \\
16.8(8.0)\end{array}$ & $\begin{array}{c}{[1]} \\
34.5(26-40) \\
32.8(10.2) \\
{[1]} \\
14(10,21) \\
16.4(7.8)\end{array}$ & $\begin{array}{c}{[2]} \\
30(23-36) \\
29.7(9.2) \\
{[2]} \\
14(11,20) \\
16.5(7.1)\end{array}$ \\
\hline $\begin{array}{l}\text { Lung Cancer Worry Scale } \\
\text { How worried are you about getting lung cancer someday? } \\
\text { Not worried } \\
\text { Worried } \\
\text { What is your current anxiety level about the results of future } \\
\text { tests/treatments? } \\
\text { Not anxious } \\
\text { Anxious } \\
\text { Impact of worry } \\
\text { Median (IQR) } \\
\text { (mean (SD)) }\end{array}$ & $\begin{array}{c}{[0]} \\
39(42.9) \\
52(57.1) \\
\\
{[1]} \\
73(81.1) \\
17(18.9) \\
{[1]} \\
3(2,4) \\
3.3(1.7) \\
\end{array}$ & $\begin{array}{c}{[0]} \\
62(37.6) \\
104(62.4) \\
{[0]} \\
133(80.6) \\
32(19.4) \\
{[1]} \\
3(2,4) \\
3.4(1.7) \\
\end{array}$ & $\begin{array}{c}{[0]} \\
39(42.9) \\
52(57.1) \\
\\
{[1]} \\
71(78.9) \\
19(21.1) \\
{[2]} \\
2(2,4) \\
3.2(1.7) \\
\end{array}$ & $\begin{array}{c}{[0]} \\
56(34.4) \\
107(65.6) \\
\\
{[1]} \\
132(81.5) \\
30(18.5) \\
{[1]} \\
3(2,4) \\
3.4(1.7) \\
\end{array}$ \\
\hline $\begin{array}{l}\text { Illness Perception Questionnaire (IPQ-R) } \\
\text { What I do can affect my risk of getting lung cancer } \\
\text { Agree } \\
\text { Disagree } \\
\text { When I think about my risk of getting lung cancer I get upset } \\
\text { Agree } \\
\text { Disagree } \\
\text { I do not know how likely it is that I might get lung cancer } \\
\text { Agree } \\
\text { Disagree } \\
\text { Finding lung cancer early can improve my chances of survival } \\
\text { Agree } \\
\text { Disagree }\end{array}$ & $\begin{array}{c}{[1]} \\
80(88.9) \\
10(11.1) \\
\quad[1] \\
39(43.3) \\
51(56.7) \\
\quad[2] \\
53(59.5) \\
36(40.5) \\
\quad[0] \\
86(94.5) \\
5(5.5) \\
\end{array}$ & $\begin{array}{c}{[3]} \\
147(90.7) \\
15(9.3) \\
{[3]} \\
71(43.8) \\
91(56.2) \\
{[3]} \\
95(58.6) \\
67(41.4) \\
{[2]} \\
152(93.3) \\
11(6.7) \\
\end{array}$ & $\begin{array}{c}{[0]} \\
84(92.3) \\
7(7.7) \\
{[1]} \\
42(46.7) \\
48(53.3) \\
{[2]} \\
40(44.9) \\
49(55.1) \\
{[0]} \\
84(92.3) \\
7(7.7) \\
\end{array}$ & $\begin{array}{c}{[2]} \\
147(91.3) \\
14(8.7) \\
{[1]} \\
75(46.3) \\
87(53.7) \\
{[1]} \\
89(54.9) \\
73(45.1) \\
{[0]} \\
151(92.6) \\
12(7.4) \\
\end{array}$ \\
\hline
\end{tabular}




\begin{tabular}{|c|c|c|c|c|}
\hline $\begin{array}{l}\text { Lung cancer would have a big impact on my life } \\
\text { Agree } \\
\text { Disagree } \\
\text { Lung cancer lasts for a long time } \\
\text { Agree } \\
\text { Disagree } \\
\text { A blood screening test can accurately detect lung cancer } \\
\text { Agree } \\
\text { Disagree }\end{array}$ & $\begin{array}{c}{[0]} \\
87(95.6) \\
4(4.4) \\
{[0]} \\
56(61.5) \\
35(38.5) \\
{[2]} \\
52(58.4) \\
37(41.6)\end{array}$ & $\begin{array}{c}{[1]} \\
157(95.7) \\
7(4.3) \\
{[3]} \\
98(60.5) \\
64(39.5) \\
{[3]} \\
92(56.8) \\
70(43.2)\end{array}$ & $\begin{array}{c}{[1]} \\
86(95.6) \\
4(4.4) \\
{[1]} \\
51(56.7) \\
39(43.3) \\
{[0]} \\
49(53.9) \\
42(46.2)\end{array}$ & $\begin{array}{c}{[1]} \\
156(96.3) \\
6(3.7) \\
{[3]} \\
91(56.9) \\
69(43.1) \\
{[0]} \\
81(49.7) \\
82(50.3)\end{array}$ \\
\hline $\begin{array}{l}\text { Lung Cancer Risk Perception } \\
\text { What are the chances that you will develop lung cancer over the next } 5 \\
\text { years? } \\
\leq 0.4 \% \text { (low risk) / Don't know } \\
\geq 1 \% \text { (high risk) } \\
\text { Compared to other people of your age and sex, how likely are you to } \\
\text { develop lung cancer over the next } 5 \text { years? } \\
\text { Less likely / Don't know } \\
\text { More likely }\end{array}$ & $\begin{array}{c}{[0]} \\
65(71.4) \\
26(28.6) \\
\\
\quad[0] \\
37(40.7) \\
54(59.3)\end{array}$ & $\begin{array}{c}0] \\
118(71.5) \\
47(28.5) \\
\\
{[1]} \\
57(34.8) \\
107(65.2)\end{array}$ & $\begin{array}{c}{[1]} \\
61(67.8) \\
29(32.2) \\
\\
{[0]} \\
31(34.1) \\
60(65.9)\end{array}$ & $\begin{array}{c}{[0]} \\
121(74.2) \\
42(25.8) \\
\\
{[0]} \\
64(39.3) \\
99(60.7)\end{array}$ \\
\hline $\begin{array}{l}\text { Health Anxiety Subscale (HAS) } \\
\text { Median (IQR) } \\
\text { (mean (SD)) }\end{array}$ & $\begin{array}{c}{[0]} \\
5(3,10) \\
7.2(5.7)\end{array}$ & $\begin{array}{c}{[0]} \\
6(4,11) \\
8.0(5.3)\end{array}$ & $\begin{array}{c}{[0]} \\
5(3,9) \\
7.0(5.8)\end{array}$ & $\begin{array}{c}{[0]} \\
6(3,12) \\
7.8(5.5)\end{array}$ \\
\hline $\begin{array}{l}\text { Impact of Events Scale } \\
\text { Intrusion score } \\
\text { Median (IQR) } \\
\text { (mean (SD)) } \\
\text { Avoidance score } \\
\text { Median (IQR) } \\
\text { (mean (SD)) }\end{array}$ & $\begin{array}{c}{[1]} \\
0.5(0,6) \\
4.2(6.9) \\
{[1]} \\
0.5(0,5) \\
4.7(8.2)\end{array}$ & $\begin{array}{c}{[0]} \\
2(0,7) \\
4.7(6.6) \\
\quad[0] \\
2(0,10) \\
6.4(8.8)\end{array}$ & $\begin{array}{c}{[0]} \\
0(0,6) \\
4.1(6.8) \\
{[0]} \\
0(0,13) \\
6.8(10.7)\end{array}$ & $\begin{array}{c}{[1]} \\
0(0,6) \\
3.8(6.4) \\
{[3]} \\
1(0,8.5) \\
5.4(8.3)\end{array}$ \\
\hline
\end{tabular}

[Missing values] *Interquartile range **Standard deviation 
Table 4. Difference between means and odds ratios for psychological measures at 3 and 6 months comparing participants in the nodule group to those in the normal CT group.

\begin{tabular}{|c|c|c|c|}
\hline Psychological Measure & $\begin{array}{l}\text { Difference } \\
\text { between means } \\
(95 \% \mathrm{Cl}) \text { at } 3 \text { months }\end{array}$ & $\begin{array}{l}\text { Difference } \\
\text { between means } \\
(95 \% \mathrm{Cl}) \text { at } 6 \\
\text { months }\end{array}$ & $\begin{array}{l}\text { P-value for } \\
\text { difference } \\
\text { between } \\
\text { means over } \\
\text { time }\end{array}$ \\
\hline \multicolumn{4}{|l|}{ Positive and Negative Affect Schedule (PANAS) } \\
\hline Positive affect score* & $1.17(-0.67,3.01)$ & $1.46(-0.39,3.30)$ & $P=0.76$ \\
\hline Negative affect score* & $0.13(-1.34,1.60)$ & $-0.05(-1.52,1.42)$ & $P=0.79$ \\
\hline \multicolumn{4}{|l|}{ Lung Cancer Worry Scale } \\
\hline Impact of worry * & $-0.01(-0.39,0.37)$ & $-0.15(-0.53,0.24)$ & $P=0.36$ \\
\hline Health Anxiety Subscale (HAS)** & $-1.00(-2.35,0.35)$ & $-0.83(-2.18,0.52)$ & $P=0.71$ \\
\hline \multicolumn{4}{|l|}{ Impact of Events Scale } \\
\hline Intrusion score** & $-0.73(-2.37,0.91)$ & $-0.24(-1.88,1.40)$ & $P=0.45$ \\
\hline \multirow[t]{2}{*}{ Avoidance score** } & $-1.99(-4.18,0.21)$ & $0.88(-1.32,3.08)$ & $P=0.003$ \\
\hline & $\begin{array}{l}\text { Odds ratios } \\
(95 \% \mathrm{Cl}) \text { at } 3 \text { months }\end{array}$ & $\begin{array}{l}\text { Odds ratios } \\
(95 \% \mathrm{Cl}) \text { at } 6 \\
\text { months }\end{array}$ & $\begin{array}{l}\text { P-value for } \\
\text { difference } \\
\text { between odds } \\
\text { ratios over } \\
\text { time }\end{array}$ \\
\hline \multicolumn{4}{|l|}{ Lung Cancer Worry Scale } \\
\hline $\begin{array}{l}\text { How worried are you about getting lung cancer } \\
\text { someday?* (worried vs. not worried) }\end{array}$ & $1.07(0.32,3.53)$ & $0.63(0.19,2.13)$ & $P=0.41$ \\
\hline $\begin{array}{l}\text { What is your current anxiety level about the results } \\
\text { of future tests/treatments?* (anxious vs. not } \\
\text { anxious) }\end{array}$ & $1.09(0.31,3.85)$ & $1.42(0.41,4.92)$ & $P=0.70$ \\
\hline \multicolumn{4}{|l|}{$\begin{array}{l}\text { Illness Perception Questionnaire } \\
\text { (IPQ-LC) }\end{array}$} \\
\hline $\begin{array}{l}\text { What I do can affect my risk of getting lung cancer* } \\
\text { (agree vs. disagree) }\end{array}$ & $0.79(0.29,2.16)$ & $1.20(0.40,3.61)$ & $P=0.56$ \\
\hline $\begin{array}{l}\text { When I think about my risk of getting lung cancer I } \\
\text { get upset* (agree vs. disagree) }\end{array}$ & $0.80(0.18,3.51)$ & $0.87(0.20,3.81)$ & $P=0.90$ \\
\hline $\begin{array}{l}\text { I do not know how likely it is that I might get lung } \\
\text { cancer* (agree vs. disagree) }\end{array}$ & $1.13(0.51,2.51)$ & $0.57(0.26,1.26)$ & $P=0.15$ \\
\hline $\begin{array}{l}\text { Finding lung cancer early can improve my chances of } \\
\text { survival* (agree vs. disagree) }\end{array}$ & $1.39(0.33,5.93)$ & $0.85(0.22,3.26)$ & $P=0.58$ \\
\hline $\begin{array}{l}\text { Lung cancer would have a big impact on my life** } \\
\text { (agree vs. disagree) }\end{array}$ & $1.17(0.15,8.91)$ & $0.78(0.10,6.11)$ & $P=0.72$ \\
\hline Lung cancer lasts for a long time* (agree vs. disagree) & $1.14(0.40,3.22)$ & $0.86(0.31,2.42)$ & $P=0.61$ \\
\hline $\begin{array}{l}\text { A blood screening test can accurately detect lung } \\
\text { cancer* (agree vs. disagree) }\end{array}$ & $1.33(0.42,4.17)$ & $1.58(0.51,4.92)$ & $P=0.76$ \\
\hline \multicolumn{4}{|l|}{ Lung Cancer Risk Perception } \\
\hline $\begin{array}{l}\text { What are the chances that you will develop lung } \\
\text { cancer over the next } 5 \text { years?* (high vs. low) }\end{array}$ & $0.85(0.25,2.91)$ & $1.85(0.54,6.33)$ & $P=0.21$ \\
\hline $\begin{array}{l}\text { Compared to other people of your age and sex, how } \\
\text { likely are you to develop lung cancer over the next } 5 \\
\text { years?* (more vs. less) }\end{array}$ & $0.75(0.32,1.77)$ & $1.63(0.68,3.91)$ & $P=0.13$ \\
\hline
\end{tabular}

*Adjusted for study centre, age group, gender, smoking status, time and baseline.

**Adjusted for study centre, age group, gender, smoking status and time. 
Table 5. Difference between $\log _{e}$ transformed means for continuous psychological measures at 3 and 6 months comparing participants in the nodule group to those in the normal CT group.

\begin{tabular}{|c|c|c|c|}
\hline Psychological Measure & $\begin{array}{c}\text { Difference } \\
\text { between loge } \\
\text { transformed } \\
\text { means } \\
(95 \% \mathrm{Cl}) \text { at } 3 \\
\text { months } \\
\end{array}$ & $\begin{array}{c}\text { Difference } \\
\text { between loge } \\
\text { transformed } \\
\text { means } \\
(95 \% \mathrm{Cl}) \text { at } 6 \\
\text { months } \\
\end{array}$ & $\begin{array}{c}\text { P-value for } \\
\text { difference } \\
\text { between loge } \\
\text { transformed } \\
\text { means over time }\end{array}$ \\
\hline Negative Affect Schedule (PANAS)* & $0.005(-0.07,0.08)$ & $-0.02(-0.10,0.06)$ & $p=0.50$ \\
\hline Lung Cancer Worry Scale* & $-0.004(-0.10,0.09)$ & $-0.05(-0.15,0.04)$ & $p=0.23$ \\
\hline Health Anxiety Subscale (HAS)** & $-0.20(-0.40,0.01)$ & $-0.17(-0.38,0.03)$ & $p=0.76$ \\
\hline Impact of Events Scale - Intrusion Score** & $-0.20(-0.48,0.07)$ & $-0.09(-0.36,0.18)$ & $p=0.34$ \\
\hline Impact of Events Scale - Avoidance Score** & $-0.34(-0.65,-0.04)$ & $-0.06(-0.36,0.24)$ & $p=0.04$ \\
\hline
\end{tabular}

*Adjusted for study centre, age group, gender, smoking status, time and baseline.

**Adjusted for study centre, age group, gender, smoking status and time. 
Supplementary table 1. Psychological measures included in the questionnaires, with a brief description of each measure.

\begin{tabular}{|c|c|c|c|c|}
\hline Psychological Measure & $\begin{array}{l}\text { Administered } \\
\text { at baseline }\end{array}$ & $\begin{array}{l}\text { Administered } \\
\text { at } 1,3 \text { \& } 6 \\
\text { months }\end{array}$ & Description & References \\
\hline $\begin{array}{l}\text { Positive and negative affect schedule } \\
\text { (PANAS) } \\
\text { Positive affect score } \\
\text { Negative affect score }\end{array}$ & $\checkmark$ & $\sqrt{ }$ & $\begin{array}{l}\text { Two 10-item scales containing positive } \\
\text { and negative statements, with 5-point } \\
\text { Likert scale (1-5) responses to give a score } \\
\text { for each scale of } 10-50^{*} \text {. Cronbach's alpha } \\
\text { for positive and negative scales ranges } \\
\text { from } 0.84-0.90 \text { dependent on the } \\
\text { reporting period used (ranging from "at } \\
\text { the moment" to "in general"). }\end{array}$ & $\begin{array}{l}\text { Watson D, Clark LA, Tellegen A. Development and validation of } \\
\text { brief measures of positive and negative affect: The PANAS } \\
\text { scales. Journal of Personality and Social Psychology. } \\
\text { 1988;54(6):1063-70. } \\
\text { Crawford JR, Henry JD. The positive and negative affect } \\
\text { schedule (PANAS): construct validity, measurement properties } \\
\text { and normative data in a large non-clinical sample. The British } \\
\text { journal of clinical psychology / the British Psychological Society. } \\
\text { 2004;43(Pt 3):245-65. Epub 2004/08/31. }\end{array}$ \\
\hline $\begin{array}{l}\text { Lung cancer worry scale (LCWS) } \\
\text { 1) How worried are you about getting lung } \\
\text { cancer someday? } \\
\text { 2) How much does your worry affect your } \\
\text { mood? } \\
\text { 3) How much does your worry affect your } \\
\text { ability to perform your daily activities? } \\
\text { 4) What is your current anxiety level about } \\
\text { the results of future tests/treatments? }\end{array}$ & $\checkmark$ & $\checkmark$ & $\begin{array}{l}\text { Modified from the cancer worry scale by } \\
\text { changing breast cancer to lung cancer and } \\
\text { by changing mammograms to future } \\
\text { tests/treatments. Four questions with 5- } \\
\text { point Likert scale responses. Questions } 2 \\
\text { and } 3 \text { were combined to give an impact of } \\
\text { worry score (range } 2-10)^{*} \text {. Answers to } \\
\text { questions } 1 \text { and } 4 \text { were dichotomised as } \\
\text { "not worried" vs. "worried" and "not } \\
\text { anxious" vs. "anxious". "Sometimes" } \\
\text { responses were categorised as "worried" } \\
\text { or "anxious." Cronbach's alpha for the } \\
\text { scale used in relation to breast and } \\
\text { prostate cancer ranges from } 0.71 \text { to } 0.86 \text {. }\end{array}$ & $\begin{array}{l}\text { Lerman C, Trock B, Rimer BK, Jepson C, Brody D, Boyce A. } \\
\text { Psychological side effects of breast cancer screening. Health } \\
\text { Psychology. 1991;10(4):259-67. } \\
\text { Brain, K., Norman, P., Gray, J., \& Mansel, R. (1999). Anxiety and } \\
\text { adherence to breast selfexamination in women with a family } \\
\text { history of breast cancer. Psychosomatic Medicine, 61, 181-187. } \\
\text { Cohen, L., Fouladi, R. T., Babaian, R. J., Bhadkambar, V. A., } \\
\text { Parker, R. A., Taylor, C. C., ... Basen-Engquist, K. (2003). Cancer } \\
\text { worry is associated with abnormal prostate specific antigen } \\
\text { levels in men participating in a community screening program. } \\
\text { Cancer Epidemiology, Biomarkers \& Prevention, 12, 610-617. } \\
\text { McCaul, K. D., Branstetter, A. D., O'Donnell, S. M., Jacobson, K., } \\
\text { \& Quinlan, K. B. (1998). A descriptive study of breast cancer } \\
\text { worry. Journal of Behavioral Medicine, 21, 565- 579. } \\
\text { Bowen, D. J., Christensen, C. L., Powers, D., Graves, D. R., \& } \\
\text { Anderson, C. A. (1998). Effects of counseling and ethnic identity } \\
\text { on perceived risk and cancer worry in African American women. } \\
\text { Journal of Clinical Psychology in Medical Settings, 5, 365-379. }\end{array}$ \\
\hline Health anxiety subscale (HAS) & & $\checkmark$ & $\begin{array}{l}\text { One of ten subscales of the health } \\
\text { orientation scale measuring presence of } \\
\text { anxious feelings associated with a } \\
\text { person's physical health. Five questions } \\
\text { with 5-point Likert scale }(0-4) \text { responses to }\end{array}$ & $\begin{array}{l}\text { Snell WE, Johnson G, Lloyd PJ, Hoover MW. The Health } \\
\text { Orientation Scale: A measure of psychological tendencies } \\
\text { associated with health. European Journal of Personality. } \\
\text { 1991;5(2):169-83. }\end{array}$ \\
\hline
\end{tabular}




\begin{tabular}{|c|c|c|c|c|}
\hline & & & $\begin{array}{l}\text { give a score of } 0-20 * \text {. Cronbach's alpha } \\
=0.82 .\end{array}$ & \\
\hline $\begin{array}{l}\text { Impact of events scale (IES) } \\
\text { 1) Intrusion score } \\
\text { 2) Avoidance score }\end{array}$ & & $\checkmark$ & $\begin{array}{l}\text { Adapted from the original scale used for } \\
\text { bereaved individuals by changing the } \\
\text { referent event to "being tested for lung } \\
\text { cancer". Fifteen questions covered } \\
\text { intrusive thoughts and avoidant behaviour } \\
\text { following lung cancer screening, with } 4- \\
\text { point Likert scale (0-3) responses to give } \\
\text { an avoidance score ranging from } 0-24^{*} \\
\text { and an intrusion score ranging from } 0-21^{*} \text {. } \\
\text { Cronbach's alpha for the original scale } \\
=0.78 \text { for the intrusion score and } 0.82 \text { for } \\
\text { the avoidance score. }\end{array}$ & $\begin{array}{l}\text { Horowitz M, Wilner N, Alvarez W. Impact of Event Scale: a } \\
\text { measure of subjective stress. Psychosomatic medicine. } \\
\text { 1979;41(3):209-18. Epub 1979/05/01. }\end{array}$ \\
\hline $\begin{array}{l}\text { Illness perception questionnaire (IPQ-R) } \\
\text { 1) What I do can affect my risk of getting } \\
\text { lung cancer } \\
\text { 2) When I think about my risk of getting } \\
\text { lung cancer I get upset } \\
\text { 3) I do not know how likely it is that I might } \\
\text { get lung cancer } \\
\text { 4) Finding lung cancer early can improve my } \\
\text { chances of survival } \\
\text { 5) Lung cancer would have a big impact on } \\
\text { my life } \\
\text { 6) Lung cancer lasts for a long time } \\
\text { 7) A blood screening test can accurately } \\
\text { detect lung cancer }\end{array}$ & $\checkmark$ & $\checkmark$ & $\begin{array}{l}\text { Based on the revised illness perception } \\
\text { questionnaire, assessing emotional } \\
\text { response generated by illness. Seven } \\
\text { questions, each selected as the item with } \\
\text { the highest factor loading in each subscale } \\
\text { in a study of ovarian cancer screening, } \\
\text { with 5-point Likert scale (1-5) responses. } \\
\text { Answers were dichotomised to "agree" vs. } \\
\text { "disagree". "Neutral" responses were } \\
\text { categorised as "disagree." Cronbach's } \\
\text { alpha for the subscales ranges from 0.79- } \\
0.89 .\end{array}$ & $\begin{array}{l}\text { Moss-Morris R, Weinman J, Petrie K, Horne R, Cameron L, Buick } \\
\text { D. The Revised Illness Perception Questionnaire (IPQ-R). } \\
\text { Psychology \& Health. 2002;17(1):1-16. } \\
\text { Lancastle D, Brain K, Phelps C. Illness representations and } \\
\text { distress in women undergoing screening for familial ovarian } \\
\text { cancer. Psychology \& Health. 2011;26(12):1659-77. }\end{array}$ \\
\hline $\begin{array}{l}\text { Lung cancer risk perception } \\
\text { 1) Absolute risk (What are the chances that } \\
\text { you will develop lung cancer over the next } 5 \\
\text { years?) } \\
\text { 2) Relative risk (Compared to other people } \\
\text { of your age and sex, how likely are you to } \\
\text { develop lung cancer over the next } 5 \text { years?) }\end{array}$ & $\checkmark$ & $\checkmark$ & $\begin{array}{l}\text { Assessed awareness of risk of developing } \\
\text { lung cancer. Absolute risk responses } \\
\text { ranged from } 1 \text { in } 1000 \text { to } \geq 1 \text { in } 10 \text { (don't } \\
\text { know option included), dichotomised to } \\
\text { "low risk" ( } 1 \text { in } 1000 \text { to } 1 \text { in } 250 \text { and don't } \\
\text { know) vs. "high risk" ( } 1 \text { in } 100 \text { to } 1 \text { in 10). } \\
\text { Relative risk was assessed using } 6 \text { possible } \\
\text { responses (don't know option included) } \\
\text { ranging from a lot less likely to much more } \\
\text { likely, dichotomised to "less likely" vs. } \\
\text { "more likely." Don't know responses were } \\
\text { categorised as "less likely." }\end{array}$ & Questions developed for the ECLS study. \\
\hline
\end{tabular}

\footnotetext{
*Higher score indicates a greater degree of the psychological outcome.
} 


\section{Highlights}

Pulmonary nodules are commonly found on CT scans screening for lung cancer (LC)

Some non-UK studies show negative psychological impacts of pulmonary nodule diagnosis

We explored psychological impacts of nodule diagnosis during LC screening in the UK There was little impact on affect, health anxiety, worry, illness perception or risk perception

There were fewer short-term avoidance symptoms in those diagnosed with nodules 